Sustinere

Journal of Environment and Sustainability

Volume 3 Issue 3 (2019) 199-212

Print ISSN: 2549-1245 Online ISSN: 2549-1253

Website: https://sustinerejes.com E-mail: sustinere.jes@iain-surakarta.ac.id

\title{
RESEARCH PAPER Women and Wastes: Study on the participation of housewives on plastic waste management in Kecandran, Salatiga, Indonesia
}

\author{
Kevin Eric Andrawina ${ }^{1}$, Ahmad Zulfikri ${ }^{1}$, Tio Roberth Ryan Maranatha1, \\ Widhi Handayani ${ }^{2 *}$ \\ ${ }^{1}$ Faculty of Economics and Business, Universitas Kristen Satya Wacana. Jl. Diponegoro 52-60 Salatiga \\ 50711, Central Java, Indonesia
}

${ }^{2}$ Faculty of Interdisciplinary Studies, Universitas Kristen Satya Wacana. Jl. Diponegoro 52-60 Salatiga 50711, Central Java, Indonesia

Article history:

Received 30 October 2019 | Accepted 28 December 2019| Available online 31 December 2019

\begin{abstract}
Plastic waste becomes a global environmental problem that is still difficult to overcome by countries over the world, including Indonesia. In fact, Indonesia is the second largest contributor of plastic waste in the world. This problem is even not only encountered by the countries, but also faced by a small town such as Salatiga, Central Java. To overcome the problem, the society should actively be the pioneer since they are the main producer of plastic waste. However, our previous research showed that the households performed limited efforts to manage the waste, and unexpectedly, any activity of waste collection was preferably motivated by financial reasons. Therefore, this study sheds light on the housewives' perception on plastic and their awareness in managing waste, especially plastic waste. The data of this quantitative study were gathered by means of interview, survey, observation, and documentation from 96 housewives in 6 RW in Kecandran, Sidomukti Sub-District, Salatiga as the participants. The results showed that approximately $60 \%$ of the housewives in Kecandran village, Sidomukti sub-district were able to differentiate which waste belonged to non-biodegradable and biodegradable as well as to understand the negative impact of plastic waste toward the environment. They also participated in managing the plastic waste by sorting them (64.58\%), participating in waste banks or Bank Sampah $(53.13 \%)$, and reducing the plastic waste $(64.58 \%)$. In addition, $85.42 \%$ of them were willing to support the government policy in reducing the use of plastic, and $40 \%$ of them participated in the payable plastic policy. The role of Bank Sampah is really important to equip the housewives with environmental knowledge. In terms of the payable plastic policy, however, their understanding is not necessarily followed by the willingness to act, which might be related to different orientations and motives.
\end{abstract}

Keywords: Environmental participation; waste bank; housewives; plastic; waste management.

${ }^{*}$ Corresponding author. E-mail: widhyandayani@gmail.com

DOI 10.22515/sustinere.jes.v3i3.90 


\section{Introduction}

Waste, which can be categorized into organic and non-organic, is a material resulted from human and natural activities that commonly do not have an economic value (Alamsyah \& Muliawati, 2013; Budiono, 2017). Moreover, plastic waste is a type of waste that often result in a negative impact on life and the environment if it is not managed effectively and efficiently (Suwerda in Maya et al., 2018). Unlike other types of waste, plastic is difficult to manage. It takes tens or even hundreds of years to recycle and decompose the plastic waste (Setyowati \& Mulasari, 2013).

Plastic waste, or plastic pollution, is the accumulation of plastic objects which becomes a global environmental problem that is still difficult to overcome by countries over the world, including Indonesia. Indonesia is also ranked as the second largest contributor of plastic waste to the sea behind China, at a rate of $0.52 \mathrm{~kg}$ of waste/person/day or equivalent to 3.22 MMT/year (Jambeck et al., 2015). According to the report of Hendiarti (2018), there were 38 million ton/year of waste increases, in which 17 million ton/year are not managed properly. $45 \%$ of the wastes is usually disposed to drain, park, or burned, while the leakage of plastic waste to the ocean reached 1.29 million ton matrix/year. It is estimated that $30 \%$ of them are found to be plastic, and unfortunately, $80 \%$ of them are from land.

The problem of plastic waste is not only encountered by a big city, but also faced by a small city such as Salatiga, Central Java. Salatiga is a municipality having an area of $56.78 \mathrm{~km}^{2}$ and is inhabited by 433,598 people. The people live in four sub-districts, i.e. Argomulyo, Sidomukti, Tingkir, and Sidorejo, which then be divided into 23 villages. In 2016, the waste production reached 386 cubic meters which consist of organic waste $(70.74 \%)$, plastic wastes $(19.65 \%)$, paper waste $(7.28 \%)$ and the rest were wood, clothes, etc.

The initial step that could be taken to overcome the plastic waste problem is providing the society a public health counseling to improve their awareness and healthy behaviors. Also, the government should take control of its citizens by establishing regulations and policies. Furthermore, the advanced development of technology, i.e. the invention of plastic recycling technology, should be an alternative to reduce plastic pollution. Aside from cleaning up the plastic waste from the oceans, which is a very significant first step but not a long-term solution, the best way to solve this problem is to change the human mindsets and habits. Hence, examining the social perception, especially housewives as the main actor of waste management, becomes important as an initial effort to overcome the plastic pollution.

Another important factor to reduce plastic pollution is by increasing society's environmental awareness. Environmental awareness is to understand the fragility of the environment and the importance of its protection. According to Ham et al. (2016), environmental awareness consists of three components, i.e. cognitive, affective, and conative. First, the cognitive aspect comprises human opinion on something, without considering whether they are right or not. Second, the affective is considered as emotional feelings toward something. Meanwhile, the conative or behavioral aspect represents the intention of an act in a certain way and is greatly influenced by the cognitive and affective aspects (Ham et al., 2016).

Although plastic waste has a significant danger and potentially causes problems for human survival, it somehow possesses advantages. If it is managed and recycled properly, plastic waste 
can result in creative products and services that give a number of benefits in expanding employment and improving the social welfare (Putra \& Yuriandala, 2010). In addition to providing economic benefits, good waste management will also be beneficial for social life, such as creating health and aesthetic environment (Wardi, 2011). Moreover, the 3R campaign (Reduce, Reuse, and Recycle) is a positive step that can be implemented to achieve waste minimization. The government has committed to reducing waste through the 3R program by $30 \%$ in 2025 , and for the plastic waste, the government is targeting a reduction of up to $70 \%$ by 2025 (Hendiarti, 2018).

However, the previous studies revealed that the majority of the households in Salatiga are not well-equipped with the knowledge of sorting and classifying waste into biodegradable and non-biodegradable as the initial step of 3R. It also found that the efforts of the Dustman (a garbage collector) to sort the waste are primarily motivated by financial benefits (Septiani et al., 2019). These findings implicate that households' environmental awareness should be questioned. According to Septiani et al. (2019), either lack of knowledge or lack of affection might be the reason why the households in Salatiga did not perform appropriate behaviors of waste management. Considering that domestic activity is mainly managed by housewives, therefore, the present study sheds light on the description of their knowledge, perception, participation, and willingness in managing plastic waste. To ensure the objective, this study is guided by the research question: "how do housewives of Kecandran village participate in managing the plastic waste?"

\section{Methods}

The present quantitative study was conducted in Kecandran village, Sidomukti sub-district, Salatiga (see Figure 1). Sidomukti is one of the sub-districts in Salatiga inhabited by 43,055 residents in 2017 (BPS Kota Salatiga, 2018). This sub-district consists of four villages, i.e. Kecandran, Dukuh, Mangunsari, and Kalicacing. Due to the time and resource limitation, this study was focused on Kecandran village which comprises approximately 1,431 households. Based on the data of the Central Bureau of Statistics (BPS Kota Salatiga, 2017), the population of Kecandran village reaches 5,645 residents in 2017, consisting of 2,866 males and 2,779 females. This study is preliminary research that aims to map the households' participation in managing the waste in Salatiga. Further studies will also be focused on other villages, i.e. Dukuh, Mangunsari, and Kalicacing.

This study was conducted from May to August 2019 and was begun by selecting participants who represent the population of Kecandran village. The object of this study was housewives since they are directly responsible for the domestic activities, including to do waste management. The number of participants was determined by referring to Slovin method (see Equation 1).

$$
n=\frac{N}{1+N(e)^{2}}
$$

As mentioned earlier, the number of households' population (n) of Kecandran village is 1,431 , and the error tolerance (e), according to Slovin method, is $10 \%$. The result of the calculation shows that this study should involve 93.25 participants at a minimum. By employing multi-stage random sampling, this study included 96 housewives as the participants. Thus, it 
could be concluded that the number of respondents in this study has represented the total population. The data were collected by means of a survey, interview, observation, and documentation. In addition, there were 96 questionnaires distributed to the participants.

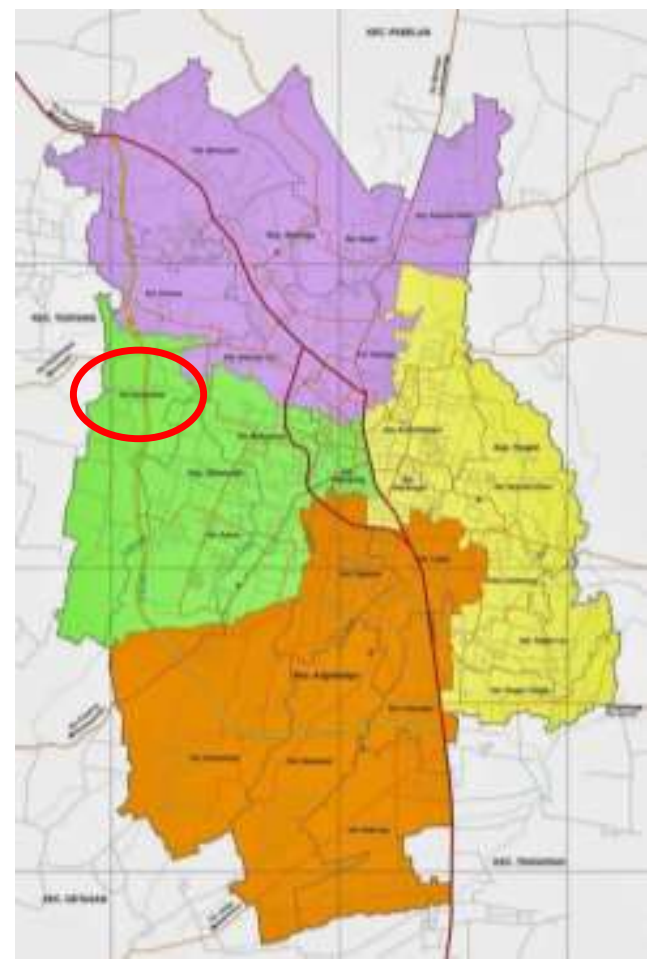

Figure 1. Administrative map of Salatiga municipality. Kecandran village is marked by red circle (source: https://peta-hd.com/peta-kota-salatiga/)

The housewives as the participants of this study must deal with the issue of plastic waste in their daily life. Additionally, they possess various educational backgrounds. Consequently, the questions addressed to the participants must be simple, easy to understand, and closely related to the situation in their daily life. The questionnaire consists of 26 questions, among which, 11 questions are composed to explore the participants' profile, while the rest is directed to seek their participation in managing the waste. In order to examine the knowledge of the housewives, the questions asked were concerned about the difference between biodegradable and nonbiodegradable wastes; the benefit of plastic as housewares; the risk of plastic wastes to the environment; and their opinion about the government policy to reduce plastic. In relation to the behavioral aspect, the questions were related to their experiences in using stuff made from plastic; the kind of plastic stuff used; the composition of wastes in their household; the way they sort the wastes; how they dispose the wastes; their participation in Bank Sampah (waste bank), and how they reduce the plastic waste. Finally, we also reveal the preference of the housewives in choosing the housewares made from certain materials, such as aluminum, plastic, glass, etc. and their willingness to participate in the payable plastic bags policy.

To maintain the research ethics and the participants' privacy, we wrote their names in initials. Furthermore, contextualization of the data is an essential aspect of this study. Therefore, 
the data were descriptively interpreted only in the context of the Kecandran village, Sidomukti sub-district, Salatiga where the data were collected. The concern of this study is not on the generalization, but rather on the contextualization and the accuracy of the situation being studied.

\section{Results}

\subsection{The Participants' profile}

The analysis of the participants' profile indicates that the housewives who are 40-50 years old, equal to 39.58\%, are the highest proportion of the participants in this study. While the age group of 20-30 years is in the lowest proportion, which is $5.21 \%$. In addition, the participants' level of education and employment also influence their responses. Education is one of the factors that influence the knowledge, understanding, and behavior of a person, especially understanding of one's concern on the environment.

Figure 2 clearly depicts the educational backgrounds of 96 housewives of Kecandran village as the participants in this study. They are mostly Junior and Senior high school graduates $(57,29 \%)$, followed by primary school graduates $(32,29 \%)$ and university graduates $(10,42 \%)$. Hence, this data indicates that the educational level of the participants is relatively low.

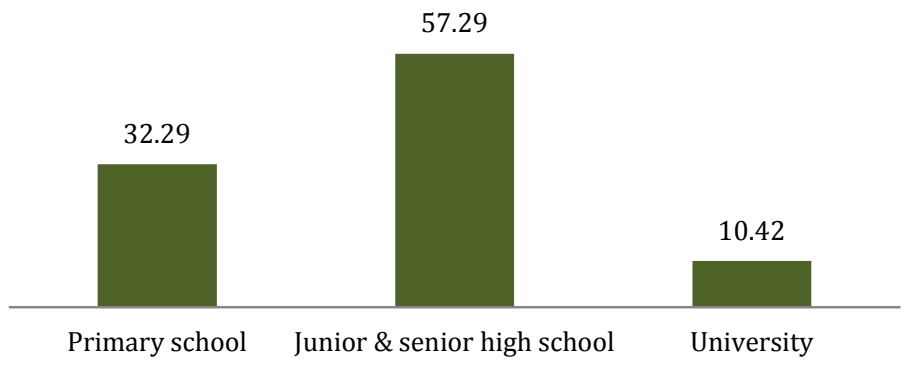

Figure 2. Level of education (\%)

The participants' educational background is closely correlated with the distribution of their occupation in Kecandran village. The data showed that their jobs are housewives $(66.67 \%)$, entrepreneurs (13.54\%), laborers (11.46), Civil Servants (5.21\%), and farmers (3.13\%) respectively. As a result, these occupations determines socio-economic status among the housewives. It is undeniable that the level of education goes hand-in-hand with one's skill and ability that will result in a promising job. Additionally, a good and promising job is consistent with the financial income. Moreover, the data of this study found that among 96 housewives in Kecandran village, 51 (53.13\%) earned less than Rp. 500,000 per month, while the rest earned ranging from Rp. 500,000 to more than Rp. 2,000,000 per month.

\subsection{The participants' preference for the choice of plastic housewares}

Figure 3 presents the houseware materials as preferred by the participants. It clearly shows that the housewives in Kecandran village mostly use housewares made from glass (41\%), followed by stainless steel (29\%), aluminum (16\%), plastic (12\%), and wood (2\%) respectively. 


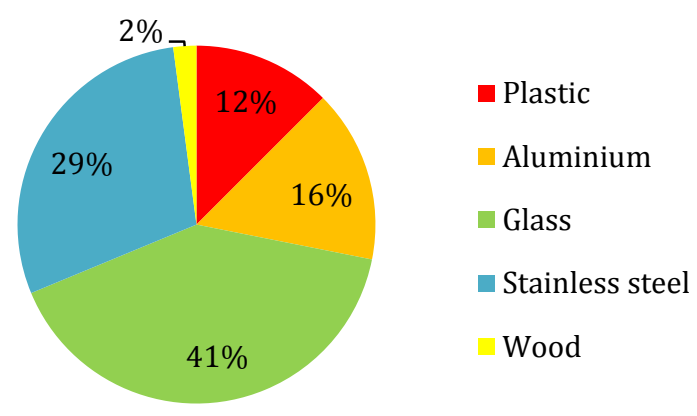

Figure 3. Preferred housewares materials (\%)

Following the participants' responses, we also asked for the reasons behind their preferences. They preferred to use housewares made from glass because the material is easy to clean. Those who chose stainless steel and aluminum are because the materials are durable, corrosive-resistant, and quickly conducts heat. Related to plastic, the results of the study found that the housewares made from plastic are less preferred by the housewives $(14 \%)$ in Kecandran village. They have some practical considerations such as its durability and is not easy broken.

Ibu A is a 48 years old woman. She graduated from senior high school and works as a housewife at her home. She prefers to use the stuff made of stainless steel because it is durable and corrosive-resistant. On the other hand, Ibu SM (53 years old), an elementary school-graduated housewife, prefers to use aluminumbased housewares due to its durability and heat conducting properties. Ibu P (50 years old) prefers glass-made housewares. To this junior high school-graduated entrepreneur, glassware is durable, corrosive-resistant, and easy to clean up. Ibu DI (41 years old) is a laborer and graduated from elementary school. She prefers to use plastic wares because in her opinion, plastic is practical to use, easy to clean up, and durable.

Although the participants showed a high preference in using glassware, this study found that all participants use stuff made from plastics, including plastic bags. This indicates that the use of plastic bags has been very common in their daily life. The finding is in line with the result of the study conducted by Septiani et al. (2019). The use of plastic bags has been considered a habit, particularly because it is used to pack the foods and to carry some stuff in a purchase transaction. The participants also said that plastic stuff and plastic bags have advantages in terms of its practical use, durability, lightness, and are easy to find at an affordable price. This finding confirms Thompson et al. (2009) who report that durability, lightweight, corrosiveresistants, and its affordable price are the advantages offered by plastic.

\subsection{The participants' knowledge of the different type of wastes}

This study found that 65 housewives $(67.71 \%)$ have understood the difference between biodegradable and non-biodegradable waste, while the other 31 (32.29\%) said they did not know. The role of Bank Sampah greatly assists their understanding of the difference. The participants who actively participate in Bank Sampah understand the difference between 
biodegradable and non-biodegradable wastes. It implicates that they get the knowledge from Bank Sampah instead of formal education.

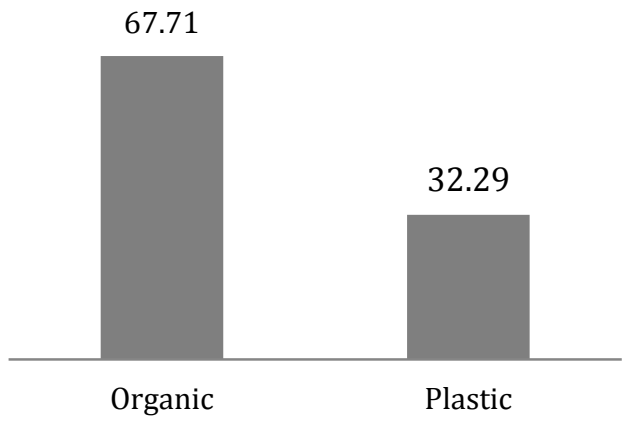

Figure 4. Type of waste disposed of by the households (\%)

Figure 4 shows that $67.71 \%$ of the participants' trash bins were filled with organic waste more quickly than plastic waste. According to them, waste from banana leaves was used to wrap tempeh and vegetable scraps from cooking results are the biggest contributor to organic waste. In addition, there were 59 participants (61.46\%) who knew the dangers of plastic waste while the rest $(38.54 \%)$ had less understanding of the dangers of plastic waste.

Ibu UZ is a 32 years old woman. She graduated from junior high school and works as a housewife at her home. According to her, the plastic waste contains chemical substances that could disturb human health, and because of this, plastic waste should be managed properly. She has been reducing the disposal of plastic waste by reusing the PET plastic bottles into handicrafts or selling them to Bank Sampah. Similarly, Ibu R (41 years old), a housewife who graduated from junior high school, explained that plastic wastes release chemical substances which could bring unhealthy effects when they are burnt. In a different case, Ibu AL (35 years old), a senior high school-graduated housewife, explained that plastic waste is non-biodegradable, and therefore, the disposal of plastic waste could deteriorate the environment. In order to reduce the use of plastic bags, she often brings her bag when she has to buy food at the market.

From the participants' responses, it could be inferred that plastic waste is dangerous. When it is burned, the waste causes air pollution which closely associated with breathing, and contains chemicals/toxins that can cause unhealthy effects. In addition, plastic materials that are difficult to decompose will cause environmental pollution. Nevertheless, there are $38.54 \%$ participants who are not well-understood about the danger of plastic waste. This lack of understanding might influence the participants' behaviors in treating plastic waste. If they do not treat the waste carefully, it could disturb their health. According to Thompson et al. (2009), in addition to the aesthetic problem, the danger of plastic includes its risk to transfer toxic substances to the ecosystem which potentially disturbs the life of the organisms because the plastics could be swallowed by them. Microplastics contain polychlorinated biphenyl (PCB), aromatic hydrocarbon, phthalates, and other chemicals added during the production process that harm the environment and ecosystem (Thompson et al., 2009). 


\subsection{The participants' waste management}

Ibu SS is a 53 years old woman. She graduated from university and works as a civil servant. She sorts the garbage to make the disposal easier. She collects plastic wastes and sells them to Bank Sampah. Nevertheless, Ibu Sn (51 years old), a bachelor who works as civil servants informed that she sorts the garbage due to consensus among the residents. Other respondents, Ibu An (31 years old) sorts the garbage to protect the environment, while to Ibu Sa (30 years old), garbage sortation is intended to make the waste processing and recycling easier.

In terms of waste management, the result of this study showed that 62 participants $(64.58 \%)$ have sorted the waste into biodegradable and non-biodegradable. They sorted the waste in order to help the dustman in collecting the waste for further processing. The waste could be then processed appropriately, i.e. organic waste can be processed into compost, while inorganic waste can be recycled and can be deposited to the local waste bank used as economically valuable products (Jumar et al., 2014). However, it is interesting to investigate the information of a participant who sorts the garbage because of the consensus of all residents. It seems that waste sortation is not conducted voluntarily, but because of the social consensus. Nevertheless, there were 34 participants (35.42\%) who did not sort the waste because they did not have free time, and because there was already a garbage collection officer.

Figure 5 presents the participants' preferences in disposing of the garbage. There were 39 participants $(40.63 \%)$ who claimed to hand over the collected garbage to the officer. The garbage was then transported to the nearest disposal station. Unfortunately, out of the 6 RWs in Kecandran, not all of them employed garbage collection officers. Only 4 RWs have garbage collectors, while the 2 RWs (RW 5 and 6) do not have garbage collectors. As a result, the housewives who live in RW 5 and 6 treat the waste by burning it. They decided to burn the garbage because this technique is considered to be faster and does not need to spend more effort to pick the garbage up to the disposal station.

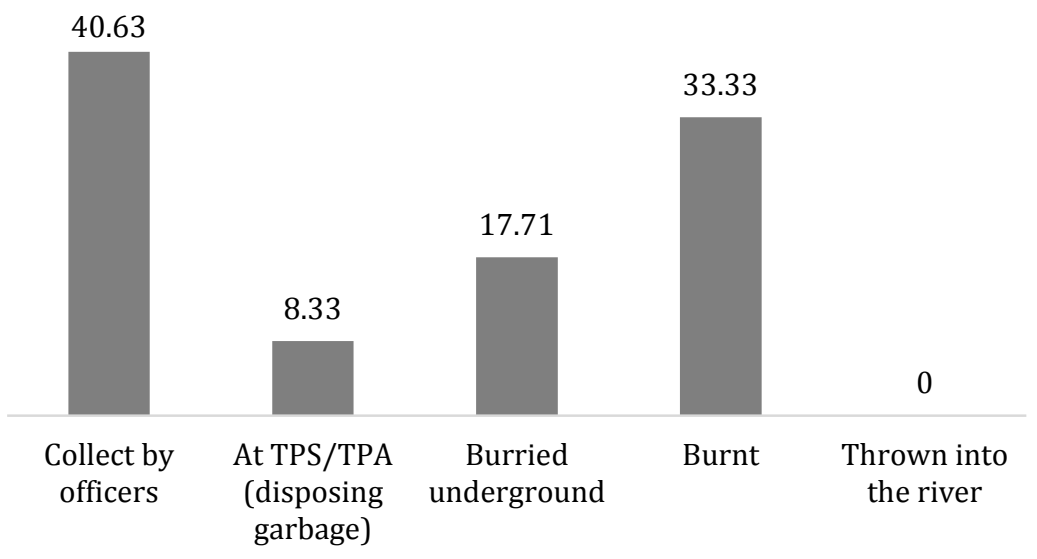

Figure 5. Respondent preferences in waste disposal (\%) 


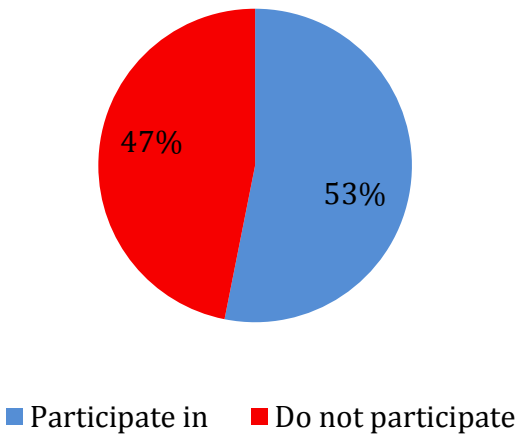

Figure 6. Participation of respondents in the waste bank or Bank Sampah (\%)

Figure 6 shows that 51 participants (53.13\%) said that they actively participate in Bank Sampah. Bank Sampah is a community-level action of which the main activity is collecting waste and processing it into useful and valuable economically products. Most of them join the group because Bank Sampah is a part of the program conducted by PKK (women regular meeting activities). Other reasons are because this activity is an effort to reduce the use of plastic waste by recycling, so as to increase income from the results of recycled crafts. The participants said that they exchange the garbage by the money they collect in the accounts they have as reported by Warsito et al. (2018).

Related to the housewives' participation in reducing the use of plastic, the results of the study showed that 62 participants (64.58\%) have taken action to reduce the consumption of plastic waste. Their claims were based on their recycling activities in the Bank Sampah, and their use of cotton bags as an alternative to replacing plastic bags when they go to the market. In addition, they also reduced the use of plastic by reusing plastic bags. On the other hand, there were 34 participants (35.42\%) who confessed that they had never reduced the use of plastic.

\subsection{The participants' willingness to support government policy in reducing plastic}

There were two questions addressed to the participants about their willingness to support the government policy in reducing the use of plastic: (1) whether they agree to support the government policy and (2) their willingness to participate in the plastic bag policy, which means if they have to pay for the plastic bags. This study found that 96 participants $(100 \%)$ agreed and supported the government policy. While $85.42 \%$ of them positively supported the policy to create a healthier environment, the others agreed to support government policies with some requirements, i.e. the substitute materials should be available $(4.17 \%)$, the substitute materials could easily be obtained at affordable price (8.33\%), and the substitute materials are safer to health $(2.08 \%)$. 


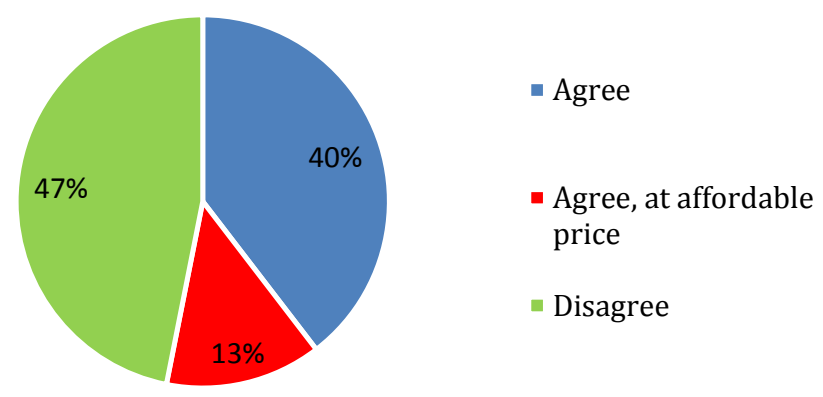

Figure 7. Respondents opinions regarding payable plastic bags (\%)

Figure 7 explains that $53 \%$ of the participants supported the payable plastic bag policy. Among them, 40\% agreed because they have a high commitment to reduce the use of plastic while the other $13 \%$ agreed with a certain condition that was the substitute material could be obtained at an affordable price. Furthermore, the study also revealed that if the price of the substitute material is not affordable, $13 \%$ of them are unwilling to support the policy. Another finding was $47 \%$ of the participants disagreed with the payable plastic bags because they had to pay additional fees which were burdensome for the consumers.

\subsection{Discussion}

This study shows that the educational level of the housewives is relatively low. Riswan et al. (2011) reported that the level of education, income level, and behavior towards family environment cleanliness are positively correlated with household waste management. Therefore, if the housewives are showing a lack of participation in managing waste, this could be well understood. However, the study finds that the housewives possess a piece of knowledge to differ the biodegradable from non-biodegradable wastes, to explain the advantages of plastic, and to understand the dangers of plastic waste.

The knowledge of the housewives might be related to the role of Bank Sampah in the village, which provides environmental education for them. Setyowati and Mulasari (2013) state that formal or informal education can be done to increase knowledge. Among the community, education improvement can be done informally by means of socialization to the community, counseling, and distribution of health promotion media in the form of posters and leaflets. According to Aryenti (2011), a waste bank is a media for collecting and sorting waste, both organic and inorganic waste. It is also a way to educate and accustom the society to sorting out, choosing, and valuing waste while developing the people's economy as suggested by Tallei et al. (2013). As also noted by Singhirunnusorn et al. (2017), changes in the way people think about household waste management to reduce waste can be done through citizen participation in community-based waste bank projects. However, if the participation is motivated by affection or by economic advantages should be of further research.

The results showed that out of the 6 RWs, only 4 RWs have Bank Sampah. Furthermore, among the 96 respondents, 51 of them joined the Bank Sampah group. Even though this number is not that big, at least with the existence of this Bank Sampah, the influence on housewives could be already seen. The knowledge of the housewives is, therefore, leading to their 
participation in waste management at the household level. The program encourages housewives to participate in waste sortation. Third, the housewives get knowledge related to the dangers of plastic waste and the participation of housewives in reducing the use of plastic waste is also quite high. Purba et al. (2014) explain that the development of a Bank Sampah will assist local governments in empowering communities to manage community-based waste wisely so that it can reduce waste transported to landfills. According to Budiana and Maryono (2017), there are already 33 Bank Sampah in Salatiga and the government targeted to add more Bank Sampah. The society's empowerment effort starts from increasing their understanding of the activities that will be carried out, including the management of plastic waste.

The knowledge of the housewives might also influence their preference in selecting the housewares materials. It is indicated by the results of the study that the majority of housewives in the District of Kecandran prefer glassware, instead of aluminum, stainless steel, or plastic. This preference is related to its practicality to clean. Nevertheless, other possible reasons might be that glassware can be stored for a long period without any risk to natural damage, and the glassware is chemically non-reactive as it is usually used in laboratories. Regarding to plastic, there are only a few housewives who choose plastic wares. The result indicates that the respondents possess knowledge of the general characteristics of materials, and this knowledge is used to decide the housewares they will use for daily activities.

Nevertheless, we found that all respondents are still using plastic in their daily life, including plastic bags. Although they have been participating in plastic reduction, for example by reducing plastic bottles and bringing their own bags for shopping, they cannot avoid the use of plastic because it is commonly used in packaging. Septiani et al. (2019) reported that in addition to its function in packaging, plastic bags are still used because it is easily obtained, inexpensive, and not yet substituted by other materials. Maulida et al. (2016) reported that cassava starch could be used to produce bioplastics which are potential to substitute conventional plastic. However, efforts have to be made to ensure that the price of bioplastic should not be expensive; otherwise, people would still choose conventional plastic. This is in line with our finding that all respondents supported the government policy in reducing plastic, but some respondents require the substitution of conventional plastic by other materials that are safe to human health and inexpensive. However, this finding shows that not all respondents - although they support government policy - show a willingness to act. The willingness to act is one component that should be performed by environmentally concerned consumers because it is related to personality factors such as locus of control, attitude, and personal responsibility (Stone et al., 1995).

In regard to willingness to act, we asked the willingness of the respondents to participate in a payable plastic bag policy. As in the previous explanation, the result showed that only $40 \%$ of housewives are willing to pay plastic bags, while $47 \%$ disagree to participate, and the rest are willing with a specific condition, i.e. if the plastic bags are sold at affordable price. This indicates that the first group would likely have an attitude based on a purely positive feeling, which is not found in the latter group. The latter is, of course, uneasy to realize as "affordable price" that would be relatively defined to different individuals. Again, the willingness with the specific condition might indicate that the respondents could be unwilling to act. 
Our results show inconsistency in the response of the respondents toward the two questions addressed. While in the first question, $85.42 \%$ of respondents agree to support the government, in the second question, only $40 \%$ of respondents were willing to participate in the payable plastic bags policy. Such a situation might be related to cognitive dissonance, which is reported by Ham et al. (2016) as a mental state of a person who experiences two or more contrary beliefs or cognitively processes a lot of information. In this case, when the first question was addressed, it is possible that the respondents answered by their positive thinking and then agree to support the policy. However, when they were faced with payable plastic bag policy, they might have thought this policy will charge them to pay for the bags. Therefore, it is possible that some respondents changed their mind and performed an agreement with the specific condition.

It seems that price becomes an important factor that influences the participation of housewives in Kecandran to the payable plastic bags policy. The behavior might be influenced by the income level, in which the housewives should take priority in spending their money to fulfill their daily life instead of paying for plastic bags. Halkos and Matsiori (2017) in their research on marine biodiversity protection, found that the respondents' ecological worldview influenced by their socioeconomic characteristics, knowledge, and their understanding of the marine biodiversity's utility. This means that knowledge and educational level are not the only factors that influence the ecological worldview of respondents and their participation in environmental conservation. Instead, income level and understanding of the function of the ecosystem are other factors which play a role in constructing the ecological worldview. Even the findings of Chan and Lau (2000) indicate that people with a low level of ecological knowledge might express a positive ecological attitude as traditional values or local wisdom could bring positive influence to environmental awareness.

In addition, it is also possible that $40 \%$ of the respondents who are willing to participate in payable plastic bags policy are not of high-level income or of high-level education. According to De Groot and Steg (2010), pro-environmental behavior is very likely to be influenced by altruistic and biosphere value orientations. Altruistic and biosphere oriented respondents tend to be self-determined in pro-environmental action. Moreover, the refusal of the latter group to support the payable plastic bags policy, which is strongly related to the price, might be related to the anthropocentric motive as reported by Gagnon \& Barton (1994). While exocentric individuals value nature for their own sake, anthropocentric feel that the environment should be maintained or protected to ensure the life quality of human (Gagnon \& Barton, 1994). This difference in motive will lead to a different action, including a difficulty to act on their tendency to conserve when faced with higher prices, as written by (Gagnon \& Barton, 1994). Therefore, strengthening the biosphere and altruistic values could be encouraged to promote proenvironmental preferences and intentions (De Groot \& Steg, 2010).

\section{Conclusion}

The results of this study indicate that the housewives in Kecandran village, Sidomukti subdistrict, Salatiga have adequate knowledge of (1) the difference between biodegradable and nonbiodegradable waste $(67.71 \%)$ and (2) the negative impact of plastic waste $(61.46 \%)$. The role of Bank Sampah is important as a media to share environmental education to the housewives. The knowledge has been applied in waste management at the household level in the form of participation in (1) waste segregation $(64.58 \%),(2)$ waste banks $(53.13 \%)$, and (3) reducing the 
plastic waste (64.58\%). The housewives (85.42\%) are willing to support the government policy in reducing plastic, while the rest agree to support the government by certain conditions. In regard to payable plastic bags, $40 \%$ of the housewives are willing to participate, while $47 \%$ are not, and $13 \%$ are willing some requirements. Finally, this study finds out that the participants' knowledge and understanding are not necessarily followed by the willingness to act, which might be related to different orientations and motives. Efforts must be conducted to strengthen personal values in order to promote pro-environmental action.

\section{References}

Alamsyah, D., \& Muliawati, R. (2013). Pilar Dasar Ilmu Kesehatan Masyarakat. Yogyakarta: Nuha Medika.

Aryenti. (2011). Peningkatan Peranserta Masyarakat Melalui Gerakan Menabung pada Bank Sampah di Kelurahan Babakan Surabaya, Kiaracondong, Bandung. Jurnal Permukiman, 6(1), 40-46.

BPS Kota Salatiga. (2017). Kecamatan Sidomukti Dalam Angka 2017. Salatiga: BPS Salatiga. Retrieved from https://salatigakota.bps.go.id/publication/2017/09/20/5a52fcccceb9211e1494994e/kec amatan-sidomukti-dalam-angka-2017.html

BPS Kota Salatiga. (2018). Salatiga Municipality in Figures 2017. Salatiga: BPS Kota Salatiga.

Budiana, M. N., \& Maryono. (2017). Inisiatif standarisasi waktu pengumpulan sampah di kota Salatiga. Jurnal Pembangunan Wilayah \& Kota, 13(3), 353-367.

Budiono. (2017). Pemanfaatan Limbah Botol Plastik Menjadi Prakarya Boneka Pinguin Sebagai Bentuk Implementasi Dari Pendidikan Lingkungan Hidup. Jurnal PINUS, 2(2), 113-118.

Chan, R. Y. K., \& Lau, L. B. Y. (2000). Antecedents of Green Purchases: A Survey in China. Journal of Consumer Marketing, 17(4), 338-357.

De Groot, J. I. M., \& Steg, L. (2010). Relationships between value orientations, self-determined motivational types and pro-environmental behavioural intentions. Journal of Environmental Psychology, 30(4), 368-378. http://doi.org/10.1016/j.jenvp.2010.04.002

Gagnon Thompson, S. C., \& Barton, M. A. (1994). Ecocentric and anthropocentric attitudes toward the environment. Journal of Environmental Psychology, 14(2), 149-157. http://doi.org/10.1016/S0272-4944(05)80168-9

Halkos, G., \& Matsiori, S. (2017). Environmental attitude, motivations, and values for marine biodiversity. Journal of Behavioral and Experimental Economics, 69, 61-70.

Ham, M., Mrčela, D., \& Horvat, M. (2016). Insights for Measuring Environmental Awareness. Ekonomski Vjesnik: Review of Contemporary Entrepreneurship, Business, and Economic Issues, 29(1), 159-176.

Hendiarti, N. (2018). Combating Marine Plastic Debris in Indonesia. In Science to Enable and Empower Asia Pacific for SDGs. Jakarta, 30 Juli 2018.

Jambeck, J. R., Geyer, R., Wilcox, C., Siegler, T. R., Perryman, M., Andrady, A., ... Law, K. L. (2015). 
Plastic waste inputs from land into the ocean. Science, 347(6223), 768-771. Retrieved from https://science.sciencemag.org/content/347/6223/768

Jumar, Fitriyah, N., \& Kalalinggi, R. (2014). Strategi Pengelolaan Sampah Rumah Tangga di Kelurahan Lok Bahu Kecamatan Sungai Kunjang Kota Samarinda. EJournal Administrative Reform, 2(1), 771-782.

Maulida, Siagian, M., \& Tarigan, P. (2016). Production of starch based bioplastic from cassava peel reinforced with Microcrystalline Cellulose Avicel PH101 using sorbitol as plasticizer. In Journal of Physics Conference Series 710 (pp. 1-7).

Maya, S., Haryono, S., \& Kholisya, U. (2018). Pemberdayaan Masyarakat Melalui Pengelolaan Sampah Menjadi Nilai Ekonomis dan Pembentukan Bank Sampah di Kelurahan Tanjung Barat. In Proceeding of Community Development, 1(2017) (p. 157).

Purba, H. D., Meidiana, C., \& Adrianto, D. W. (2014). Waste Management Scenario through Community Based Waste Bank: A Case Study of Kepanjen District, Malang Regency, Indonesia. International Journal of Environmental Science and Development, 5(2), 212-216.

Putra, H. P., \& Yuriandala, Y. (2010). Studi Pemanfaatan Sampah Plastik Menjadi Produk dan Jasa Kreatif. Jurnal Sains \&Teknologi Lingkungan, 2(1), 21-31.

Riswan, R., Sunoko, H. R., \& Hadiyarto, A. (2011). Pengelolaan sampah rumah tangga di Kecamatan Daha Selatan. Jurnal Ilmu Lingkungan, 9(1), 31-38.

Septiani, B. A., Arianie, D. M., Risman, V. F. A. A., Handayani, W., \& Kawuryan, I. S. S. (2019). Pengelolaan Sampah Plastik di Salatiga: Praktik dan tantangan. Jurnal Ilmu Lingkungan, 17(1), 90-99.

Setyowati, R., \& Mulasari, S. A. (2013). Pengetahuan dan perilaku ibu rumah tangga dalam pengelolaan sampah plastik. Kesmas: National Public Health Journal, 7(12), 562-566.

Singhirunnusorn, W., Donlakorn, K., \& Kaewhanin, W. (2017). Household Recycling Behaviours and Attitudes toward Waste Bank Project: Mahasarakham Municipality. Journal of ASIAN Behavioural Studies, 2(5), 17-26.

Stone, G., Barnes, J. H., \& Montgomery, C. (1995). ECOSCALE: A scale for the measurement of environmentally responsible consumer. Psychology \& Marketing, 12(7), 595-612.

Tallei, T. E., Iskandar, J., Runtuwene, S., \& Filho, W. L. (2013). Local Community-based Initiatives of Waste Management Activities on Bunaken Island in North Sulawesi, Indonesia. Research Journal of Environmental and Earth Sciences, 5(12), 737-743.

Thompson, R. C., Moore, C. J., vom Saal, F. S., \& Swan, S. H. (2009). Plastics, the environment and human health: current consensus and future trends. Philosophical Transactions of the Royal Society B, 364, 2153-2366.

Wardi, I. N. (2011). Pengelolaan Sampah Berbasis Sosial Budaya: Upaya Mengatasi Masalah Lingkungan di Bali. Jurnal Bumi Lestari, 11 No 1, 167-177. Jurnal Bumi Lestari, 11(1), 167177.

Warsito, B., Suparti, S., Raharjo, M., Santoso, R., Yasin, H., \& Sumiyati, S. (2018). Pelatihan Pemanfaatan Sampah Plastik Berpotensi Ekonomis bagi Nasabah Bank Sampah Sempulur Asri. In Prosiding Seminar Nasional Unimus (pp. 368-373). 